\title{
Exact Analytical Analysis of Dye-Sensitized Solar Cell: Improved Method and Comparative Study
}

\author{
Renu Guliani ${ }^{\mathrm{a}}$, Amit Jain ${ }^{\mathrm{b}}$ and Avinashi Kapoor ${ }^{\mathrm{a},{ }^{*}}$ \\ ${ }^{a}$ Department of Electronic Science, University of Delhi South Campus, New Delhi, India \\ ${ }^{b}$ Department of Electronics, Rajdhani College, University of Delhi, New Delhi, India
}

\begin{abstract}
Dye sensitized solar cell (DSSC) being one of the main focus in area of photovoltaic after silicon solar cell, modeling and estimating their parameters becomes important for their analysis and enhancement in their performance. We have proposed an analytical approach having no approximation for extracting various parameters of DSSC using a well known Lambert $\mathrm{W}$-function technique. The model used in present work is single diode model where effect of capacitance and inductance has been neglected. We have applied our method to six different DSSCs, which were previously reported in literature for both treated (Carboxylic acid treatment) as well as non treated solar cell. Plots of various parameters including I-V relations of different solar cells are presented in this article. To validate the present method proposed in extracted parameters are compared with those present in literature. The results thus obtained demonstrate that this method proves to be superior to available methods and can be extensively applied for analyzing dye sensitized solar cells.
\end{abstract}

Keywords: Dye sensitized solar cell, equivalent circuit, parameter extraction, Lambert w-function.

\section{INTRODUCTION}

For past several decades research in the field of photovoltaic has progressed from first generation solar cell to third generation solar cell. The dominance of solid state device which converts photons to electrons is now being challenged by new technologies. Few of them are organic, hybrid organic-inorganic, dye-sensitized solar cells (DSSCs), nanotechnology and plasmonic solar cells. Newly developed techniques offer the prospect of cheap fabrication together with other attractive features, such as flexibility, bifacial configuration- allowing them to capture light from all angles. One of the promising devices having these advantages is dye-sensitized solar cell (DSSC) also referred as Gratzel cell after its inventor Michael Gratzel [1-5].

DSSC is an electrochemical device. It consists of mesoporous semiconductor such as titanium oxide $\left(\mathrm{TiO}_{2}\right)$ wetted with photoactive dye and plunged into a liquid electrolyte [3] and [6]. It differs from the conventional semiconductor devices as it separates the function of light absorption from charge carrier transport. The $\mathrm{TiO}_{2}$ consists of nanoparticles sintered to form a connected network and plays a fundamental role in device functioning. It acts as a substrate for dye, controls the energy alignment of the excited state of the dye which eventually controls the charge transfer and it is the main source of electron recombination.

Equivalent circuit analysis is a controlling tool for designing high performance DSSC $[7,8]$. Several models of a DSSC are traced in the literature [9-12]. Single diode model [13-16] has been reported many times.

*Address correspondence to this author at the Department of Electronic Science, University of Delhi South Campus, New Delhi, India; Tel: +91-8826775434; Fax: +91-24110606;

E-mail: Avinashi_kapoor@yahoo.com
The present work dealt with study of electrical characteristics which is described in detail taking into account series and shunt resistance to determine the current-voltage relation and hence extraction of various parameters such as open circuit voltage $\left(\mathrm{V}_{\mathrm{oc}}\right)$, short circuit current $\left(\mathrm{I}_{\mathrm{sc}}\right)$, dynamic series and shunt resistance $\left(\mathrm{R}_{\mathrm{s} 0}, \mathrm{R}_{\mathrm{sh} 0}\right)$, maximum power point $\left(\mathrm{P}_{\mathrm{m}}\right)$ and fill factor $(\mathrm{FF})$ of DSSC having $\mathrm{TiO}_{2}$ electrode coated with carboxylic acid as well as non treated DSSC.

Due to transcendental nature of I-V relation, various efforts have been made by researchers to solve such relations for extracting various parameters. We have used Lambert Wfunction technique [17] to extract various parameters of different DSSCs (treated as well as non treated) and presented a detailed discussion of DSSC basic parameters. We have also compared them with those available in literature to validate the present study.

\section{EQUIVALENT CIRCUIT ANALYSIS OF DSSC}

The development of a device is essentially based on understanding the physical phenomenon which governs its operation. For DSSC the key parameters which govern the device mechanism are: internal resistance, open circuit voltage, short circuit current, ideality factor, maximum power and fill factor. The single diode circuit analysis for a conventional solar cell can be extended to evaluate a DSSC electric mechanism.

The output of a cell is analyzed using model given in Fig. (1).

The equation of the equivalent circuit can be written in the form:

$i=\mathrm{I}_{p h}-\mathrm{I}_{0}\left(\mathrm{e}^{\frac{V+i R_{s}}{n K}}-1\right)-\frac{V+i R_{s}}{R_{s h}}$ 


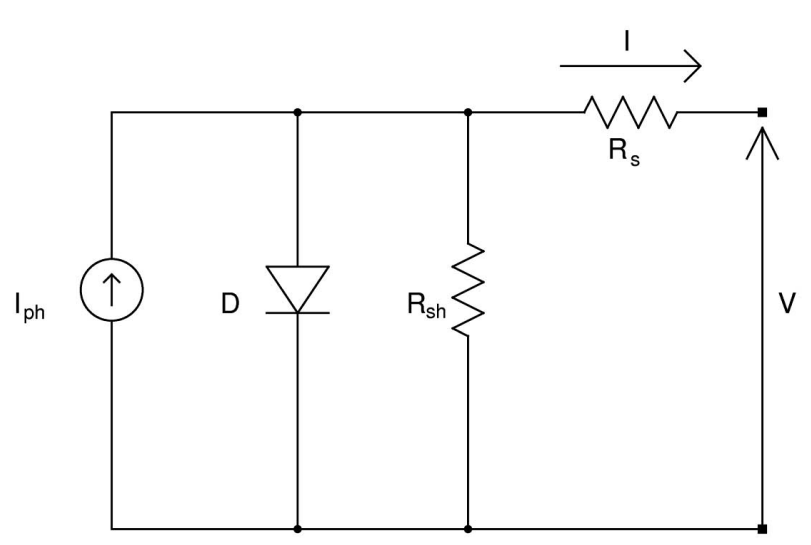

Fig. (1). Equivalent circuit of dye sensitized solar cell (DSSC).

Where $\mathrm{K}=\mathrm{kT} / \mathrm{q}$

In this equation $\mathrm{I}_{\mathrm{ph}}$ represents photocurrent, $\mathrm{I}_{0}$ Initial current , $\mathrm{R}_{\mathrm{s}}$ series resistance $\mathrm{R}_{\mathrm{sh}}$ shunt resistance, $\mathrm{n}$ ideality factor , $\mathrm{q}$ elementary electric charge , $\mathrm{k}$ Boltzmann constant and $\mathrm{T}$ temperature. The value of ideality factor (n) for DSSC is above 2.0 and for silicon solar cell it is between 1 and 2 [16]. For high efficiency DSSC $\mathrm{n}$ is between 2.2 and $2.7[13,16,18]$.

Different processes associated with various components in equivalent circuit diagram (ECD) of DSSC are as follows:

The current source $\mathrm{I}_{\mathrm{ph}}$ corresponds to the current generated when the sun light is absorbed by the sensitizer. This sun light is directed to the surface of a wide band gap semiconductor. At the interface charge separation takes place via photo induced electron injection from the dye into the conduction band of semiconductor and then to charge collector [1].

Equation (1) is transcendental in nature hence it is not possible to solve it explicitly. The explicit solution for current and voltage can be expressed using Lambert W- function.

$$
\begin{aligned}
V= & -i R_{s}-i R_{s h}+\mathrm{I}_{p h} R_{s h} \\
& -n K \text { LambertW }\left(\frac{\mathrm{I}_{0} R_{s h} \mathrm{e}}{n K}\right)+\mathrm{I}_{0} R_{s h} \\
i= & -\frac{1}{R_{s}}\left(V-\left(- \text { LambertW }\left(-\frac{R_{s h} \mathrm{I}_{0} R_{s h} \mathrm{e}^{\frac{R_{s h}\left(R_{s p h} \mathrm{I}_{p h}+R_{s} \mathrm{I}_{0}+V\right)}{n K\left(R_{s h}+R_{s}\right)}}}{-R_{s} n K-R_{s h} n K}\right)\right.\right. \\
& \left.\left.+\frac{R_{s h}\left(R_{s} \mathrm{I}_{p h}+R_{s} \mathrm{I}_{0}+V\right)}{n K\left(R_{s h}+R_{s}\right)}\right) n K\right)
\end{aligned}
$$

\subsection{Internal Resistance}

Electrochemical impedance spectroscopy (EIS) has been used to analyze internal resistance of DSSC and three internal resistances have been found. [19, 20]. In Plot of DSSC three semicircles are observed in the frequency range of $10^{-1}$ $-10^{6} \mathrm{~Hz}$ which correspond to three types of impedance namely $Z_{1}, Z_{2}$ and $Z_{3}$. $Z_{1}$ is related to charge transport at the $\mathrm{Pt}$ counter electrode in the high frequency ( $\mathrm{KHz}$ range) region. $Z_{2}$ is the impedance observed in middle frequency (10$100 \mathrm{~Hz}$ ) region at $\mathrm{TiO}_{2} /$ dye/ electrolyte interface. Impedance $Z_{3}$ due to Nernstian diffusion is prominent in low frequency $(\mathrm{m} \mathrm{Hz})$ region. [19]. Origin of $Z_{1}$ and $Z_{3}$ are similar to those reported by Kern et al. [21]. Han L et al. [19] proved that $Z_{2}$ is impedance of diode.

EIS of a DSSC prepared at our centre having $\mathrm{TiO}_{2}$ as electrode and platinum as counter electrode using potentiostat (Gamry potentiostat and analyzer) also showed similar results Fig. (2)

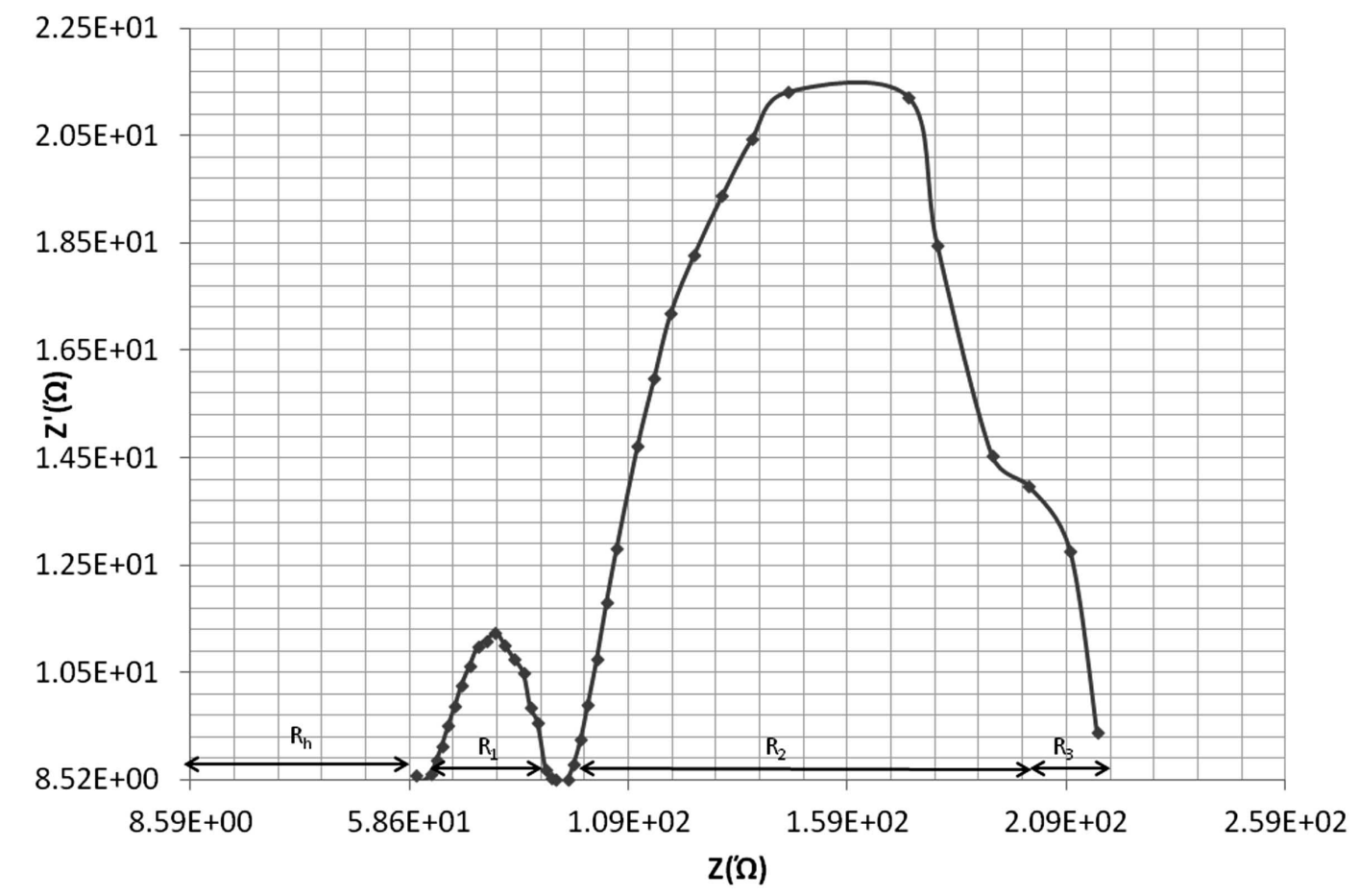

Fig. (2). Electrochemical Impedance spectrum of DSSC. 


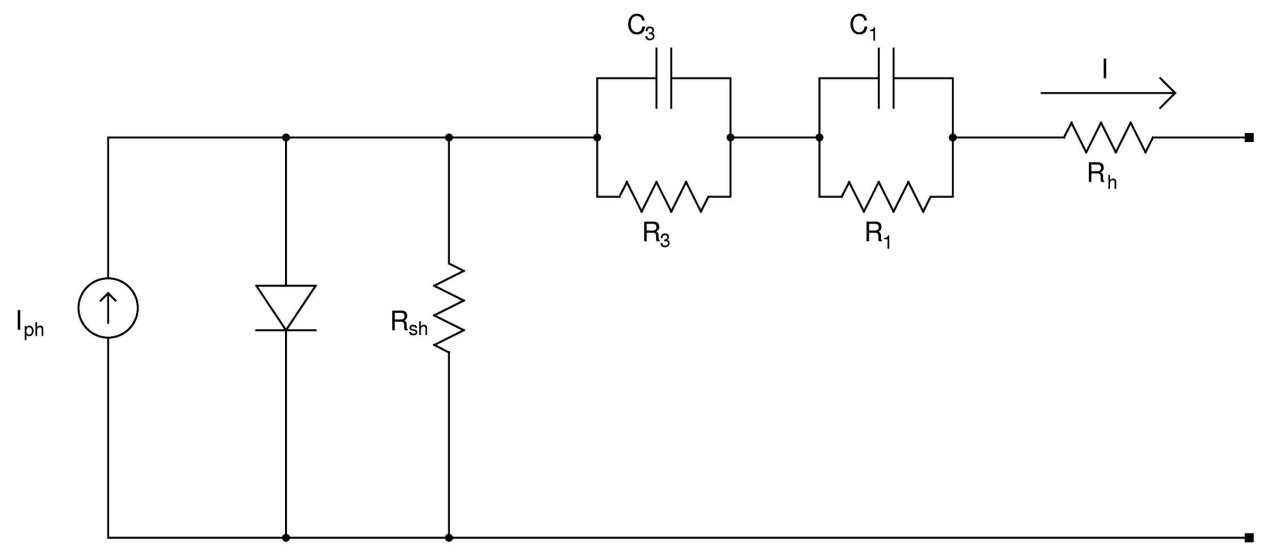

Fig. (3). Equivalent circuit of actual dye sensitized solar cell (DSSC).

Hence it can be concluded that the actual DSSC model consists of series, shunt resistive and capacitive parts Fig. (3).

$Z_{1}$ is parallel combination of $R 1$ and $C_{1}, Z_{2}$ is parallel combination of $\mathrm{R}_{2}$ and $\mathrm{C}_{2}$, and $\mathrm{Z}_{3}$ is parallel combination of $\mathrm{R}_{3}$ and $\mathrm{C} 3$ Fig. (3).

The real part of $Z_{1}$ is related to charge -transfer process occurring at the $\mathrm{Pt}$ counter electrode denoted by $\mathrm{R}_{1}$ and the imaginary part $\mathrm{C}_{1}$ is capacitance of Helmholtz double layer at the electrodes. The order of $\mathrm{C}_{1}$ is estimated to be 1.0 to 2.0 $\mu F$. Similarly $R_{2}$, the real part of $Z_{2}$ corresponds to diode like behavior in DSSC. The capacitive part of $Z_{2}$ is of the order 0.3 to $40 \mathrm{mF}$. Resistance $R_{3}$ of $Z_{3}$ is proportional to the distance between TCO and Pt counter electrode and is related to diffusion of iodide and trioxide within the electrolyte. As the values of the capacitance calculated is lower than the values reported by Han et al. [19], we have neglected the effect of capacitance.

The series resistance $R_{s}$ can be written as

$$
\mathrm{R}_{\mathrm{s}}=\mathrm{R}_{\mathrm{h}}+\mathrm{R}_{1}+\mathrm{R}_{3}
$$

Where $R_{h}$ is the sheet resistance of TCO glass substrate.

The shunt resistance $\mathrm{R}_{\mathrm{sh}}$ is attributed to slow back electron transfer rate from $\mathrm{TiO}_{2}$ to electrolyte in $\mathrm{TiO}_{2} /$ dye/ electrolyte interface.

Dynamic resistances $R_{s 0}$ and $R_{\text {sh0 }}$ are tangential values at current and voltage axes of current-voltage plots of solar cell. These values have been used by several people for determining solar cell parameters [14]. Mathematically they are evaluated as:

$$
\mathrm{R}_{\mathrm{s} 0}=-(\partial V / \partial i)_{V=V_{o c}}
$$

$\mathrm{R}_{\mathrm{s} 0}=\frac{\partial V}{\partial t}=\frac{\text { Lambertw }\left(\frac{\left.\mathrm{I}_{0} R_{s h} \mathrm{e}^{-\frac{R_{s h}\left(i-\mathrm{I}_{p h}-\mathrm{I}_{0}\right)}{n K}}\right)}{n K}\right) R_{s h}}{1+\text { LambertW }\left(\frac{\mathrm{I}_{0} R_{s h} \mathrm{e}^{-\frac{R_{s h}\left(i-\mathrm{I}_{p h}-\mathrm{I}_{0}\right)}{n K}}}{n K}\right)}$

$\mathrm{R}_{\mathrm{sh} 0}=-(\partial V / \partial i)_{i=I_{s c}}$

$$
\mathrm{R}_{\mathrm{sh} 0}=-R_{s}-R_{s h}+\frac{\operatorname{LambertW}\left(\frac{\left.\mathrm{I}_{0} R_{s h} \mathrm{e}^{-\frac{R_{s h}\left(i-\mathrm{I}_{p h}-\mathrm{I}_{0}\right)}{n K}}\right)}{n K}\right) R_{s h}}{1+\text { LambertW }\left(\frac{\mathrm{I}_{0} R_{s h} \mathrm{e}^{-\frac{R_{s h}\left(i-\mathrm{I}_{p h}-\mathrm{I}_{0}\right)}{n K}}}{n K}\right)}
$$

The current voltage curves for six different DSSC have been plotted in Fig. (4). Cell1 (Ishabashi et al. [14]), Cell2 (Murayama et al. [15]), Cell3 (Murayama et. al. Experimental [15]), Cell4 (Murayama et. al. Non Treated [15]), Cell5 (Seema Rani et al. [22]), Cell6 (Hanmin et al. [23])

\subsection{Open Circuit Voltage}

Expressions for Open circuit Voltage can be obtained by substituting $\mathrm{i}=0$ in eq. 2

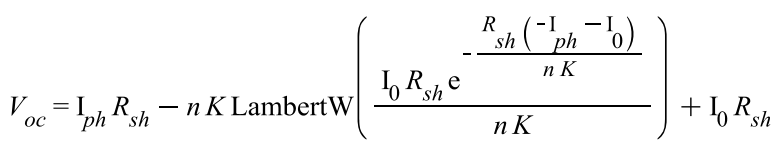

An analytical investigation of open circuit voltage governs the attainable power from the device which is the maximum voltage that a device can generate. Open circuit voltage depends upon certain factors such as temperature, light intensity, electrode thickness and ideality factor. This tells us about the physical mechanism governing the device operation.

Two oppositely varying temperature dependent factors affect the open circuit voltage: as temperature increases diffusion of charge increases and hence charge mobility, this results in increase in open circuit voltage [24, 25] whereas charge recombination rate increases with increase in temperature thus resulting in drop in open circuit voltage Fig (5).

Dependence of $\mathrm{V}_{\mathrm{oc}}$ on intensity is an interesting phenomenon from research point of view. As intensity increases, charge generation rate increases and hence chemical potential within the device leading to increase in $\mathrm{V}_{\mathrm{oc}}$. On the other hand increased intensity reduces the lifetime of charge leading to decrease in chemical potential which results in decrease in $\mathrm{V}_{\mathrm{oc}}$. However dominant among two is charge generation and hence $\mathrm{V}_{\mathrm{oc}}$ increases. 


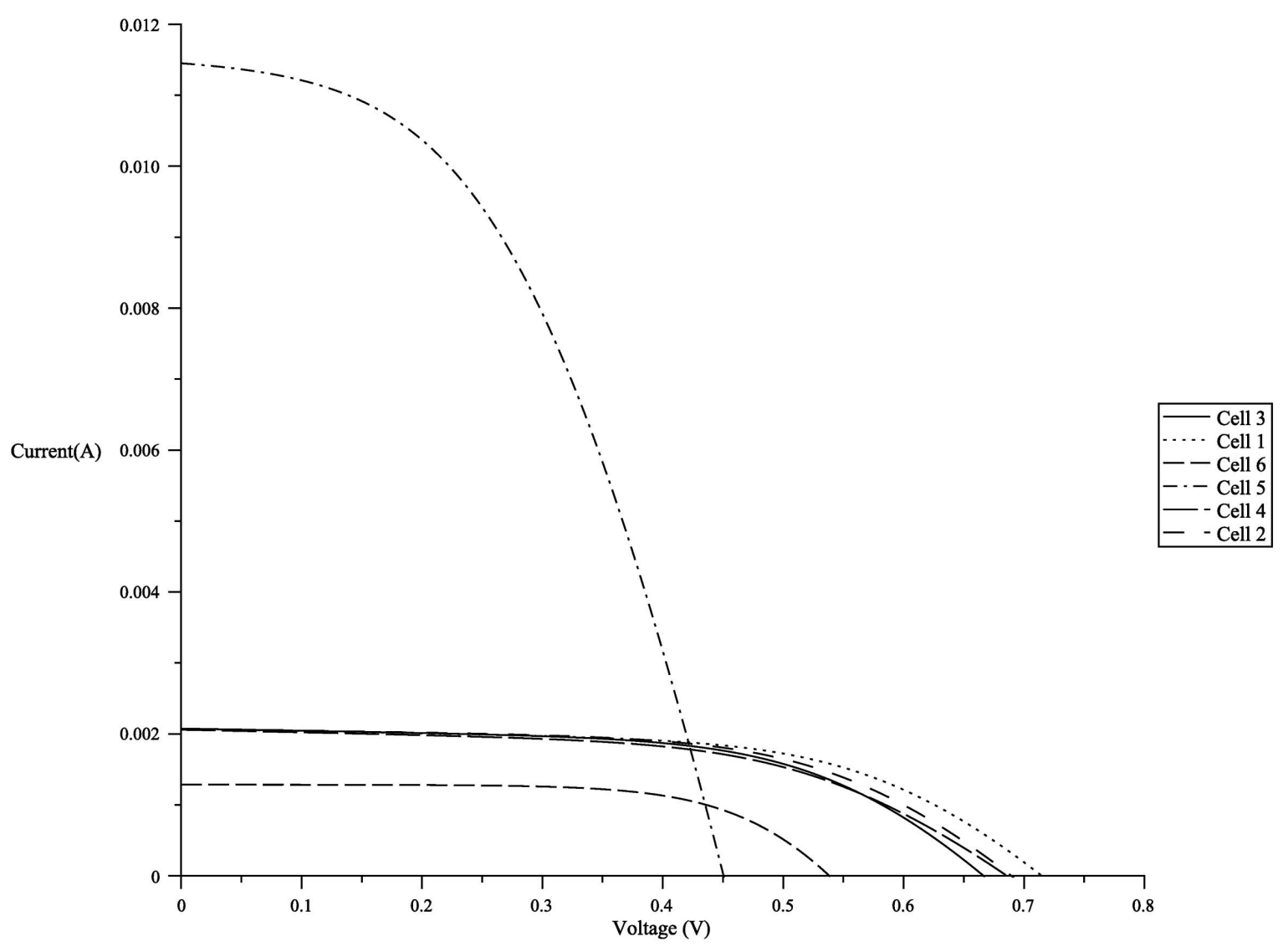

Fig. (4). Current (I) vs. Voltage (V) characteristics for six different cells.

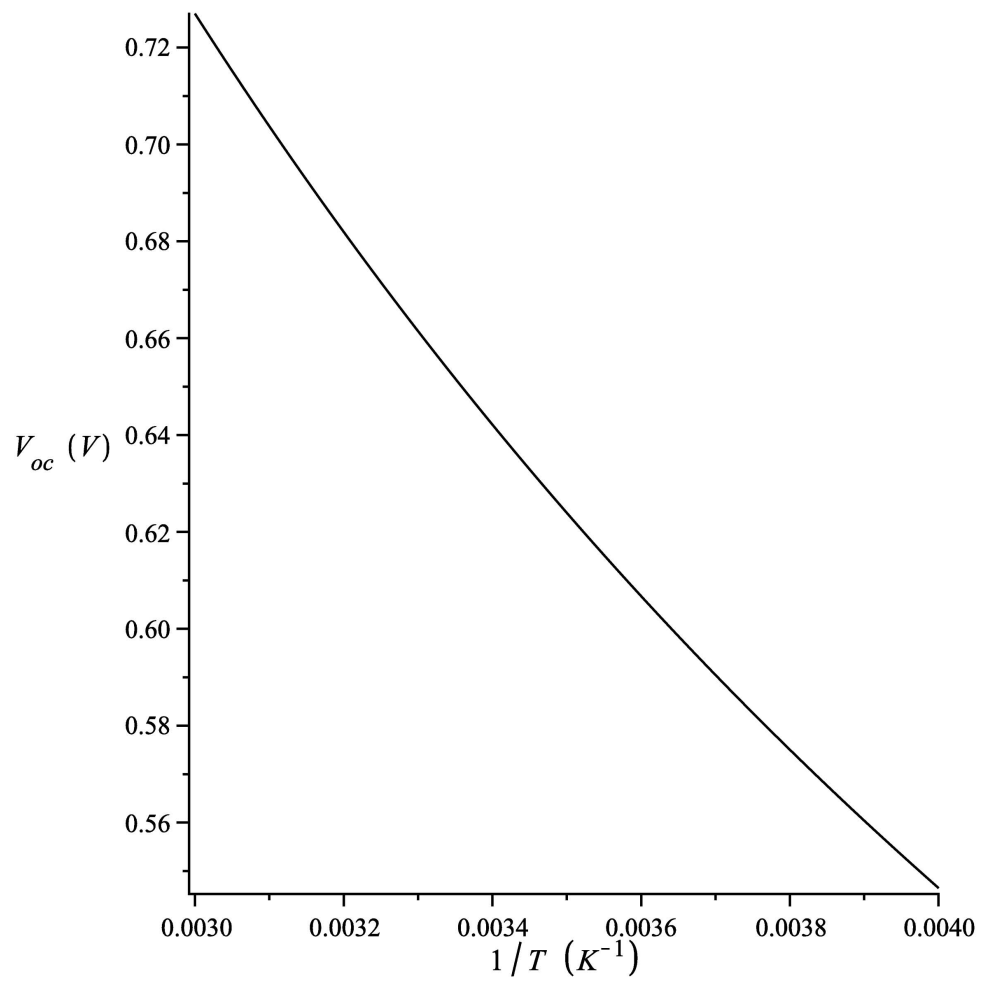

Fig. (5). Open circuit voltage $\left(\mathrm{V}_{\mathrm{oc}}\right)$ vs. 1/T.

The Variation of $\mathrm{V}_{\mathrm{oc}}$ not only depends on temperature, light intensity but also on electrode thickness. Thickness dependence can be explained by electron dilution effect. As depth of electrode increases, the absorption of intensity decreases resulting in decrease in charge density and hence $\mathrm{V}_{\mathrm{oc}}$ [26]. 


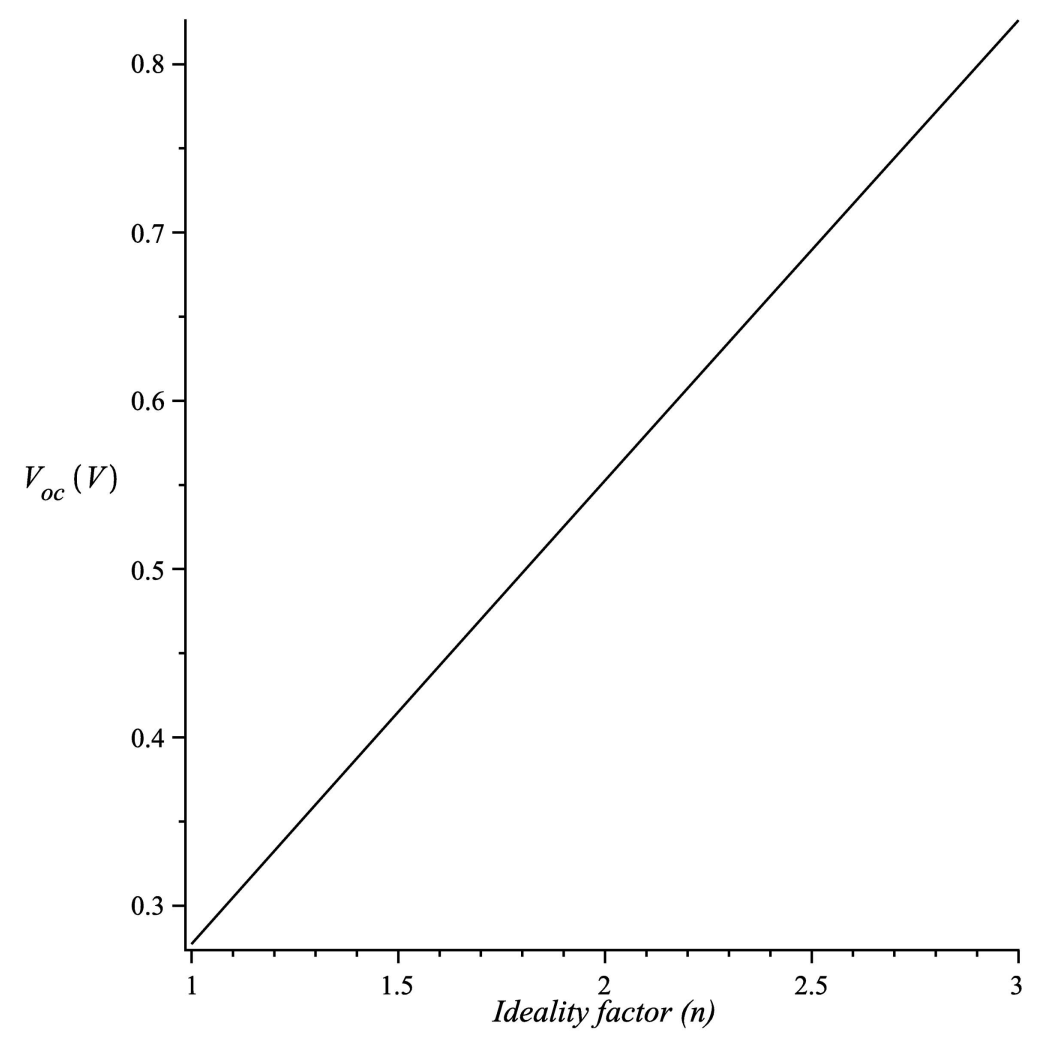

Fig. (6). Open circuit voltage $\left(V_{o c}\right)$ vs. ideality factor (n).

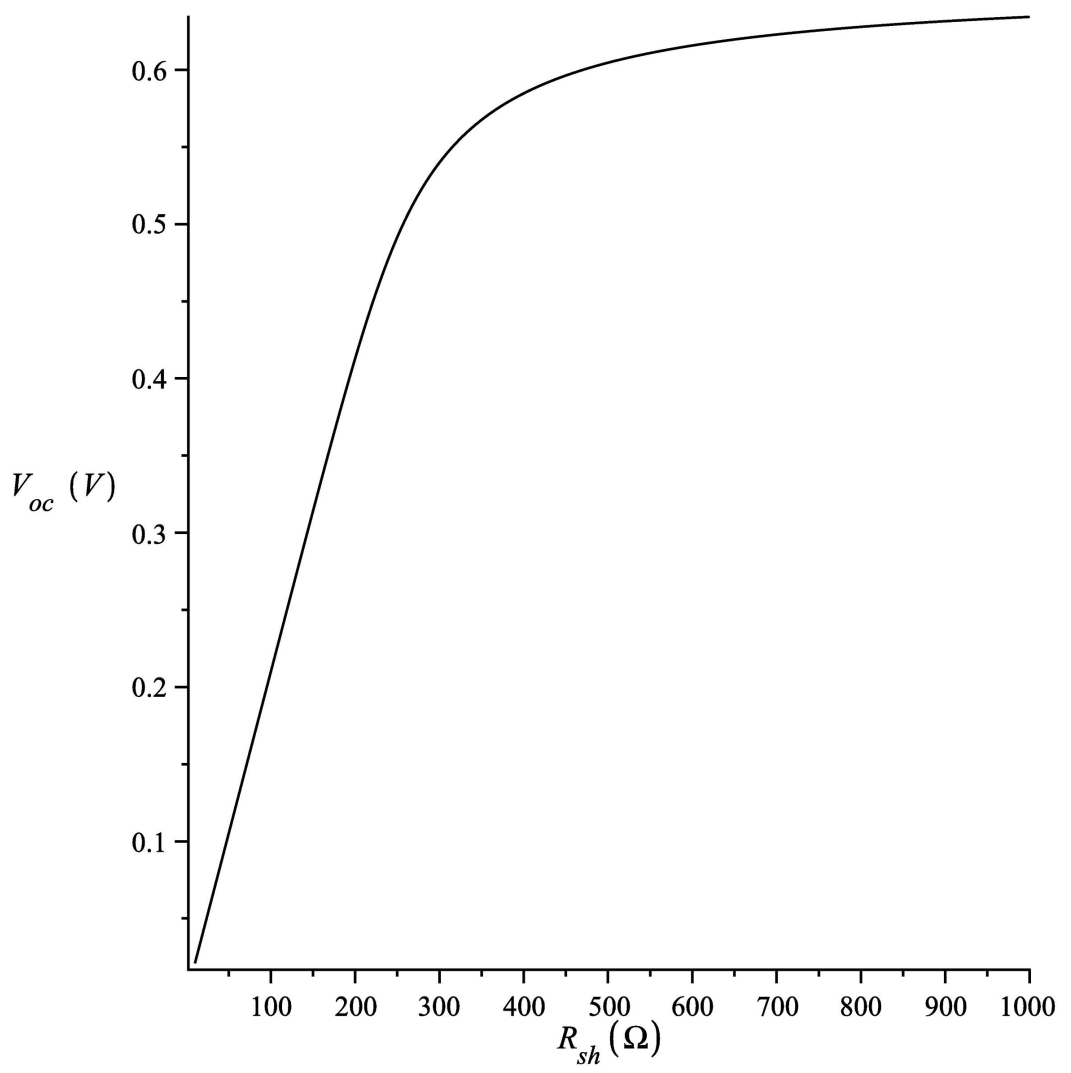

Fig. (7). Open circuit voltage $\left(V_{o c}\right)$ vs. shunt resistance $\left(R_{s h}\right)$.

Various curves have been plotted to observe the effect of change in $\mathrm{V}_{\mathrm{oc}}$ with ideality factor Fig. (6) and shunt resistance
Fig. (7). It has been demonstrated that $V_{o c}$ is not affected for higher values of $\mathrm{R}_{\mathrm{sh}}$ (for values higher than $1000 \mathrm{ohms}$ ). 


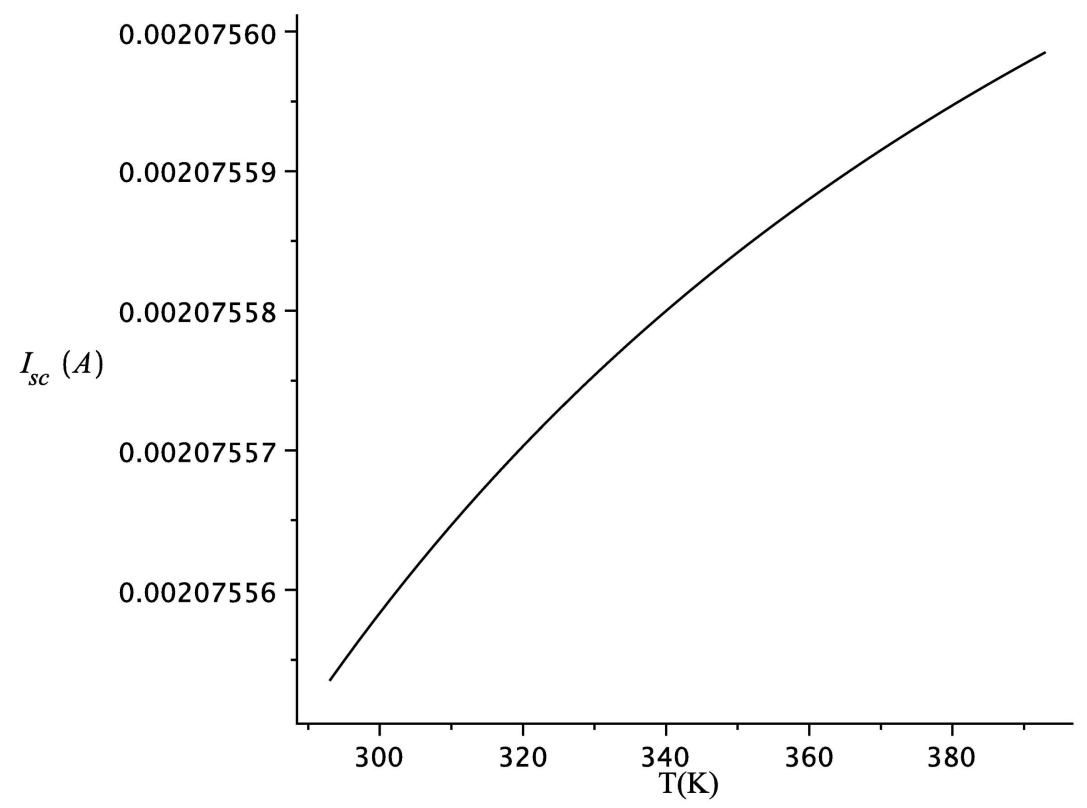

Fig. (8). Short circuit current $\left(I_{s c}\right)$ vs. temperature (T).

\subsection{Short Circuit Current}

Expression for Short Circuit Current can be obtained by substituting $\mathrm{V}=0$ in eq. 3

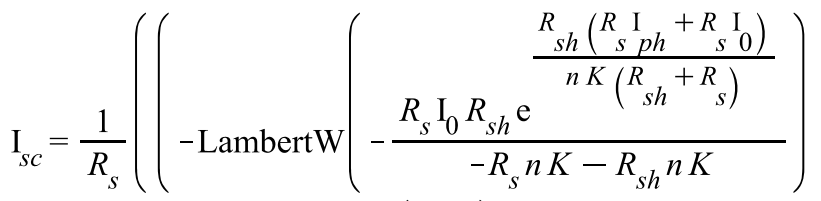

$$
\begin{aligned}
& \left.\left.+\frac{R_{s h}\left(R_{s} \mathrm{I}_{p h}+R_{s} \mathrm{I}_{0}\right)}{n K\left(R_{s h}+R_{s}\right)}\right) n K\right)
\end{aligned}
$$

Short circuit current $\left(\mathrm{I}_{\mathrm{sc}}\right)$ is another parameter significant in determining the efficiency and fill factor of any solar cell. Different ways to improve the $\mathrm{I}_{\mathrm{sc}}$ are: one to develop a dye which can absorb light of longer wavelengths and other to increase the extent of light trapping in $\mathrm{TiO}_{2}$ layer, which makes DSSCs a better choice in respect of improved $I_{s c}$ as compared to conventional silicon solar cell. Another factor is rate of recombination which is comparatively longer in comparison to conventional solar cells. Though for Si solar cell $\mathrm{I}_{\mathrm{sc}}$ increases with increase in temperature at the rate of $0.06 \%$ $/{ }^{0} \mathrm{C}$ while authors observed no significant change in case DSSC [27-29] Fig. (8).

Thickness of electrode is another factor which affects the short circuit current. As the thickness of electrode increases $\mathrm{I}_{\mathrm{sc}}$ first increases abruptly, after reaching a peak value, starts decreasing gradually. This behavior pertains to the fact that thicker electrode can absorb more photons and hence higher $\mathrm{I}_{\mathrm{sc}}$, after attaining thickness greater than penetration depth, photons will not be able to generate electrons leading to saturation in $\mathrm{I}_{\mathrm{sc}}$. Then due to increase in recombination, the number of electrons decreases and hence $\mathrm{I}_{\text {sc }}$ decreases [24]. The variation of short circuit current $I_{S C}$ with ideality factor $n$ is shown in Fig. (9). It is observed that $I_{s c}$ increases steeply till $n<2$ and is approximately constant for $n>2$.

\subsection{Maximum Power Point}

The power output of DSSC is given as:

$$
\mathrm{P}=\mathrm{VI}
$$

$\mathrm{I}$ and $\mathrm{V}$ are instantaneous current and voltage values at output terminals. The power output of DSSC increases with increase in value of voltage/current, reaches a maximum value at optimum value of voltage /current and then starts decreasing, reaches zero value at open circuit voltage/short circuit current. The maximum power point can be obtained by determining the maxima of output power $\left(\mathrm{P}_{\mathrm{m}}\right)$ where $\mathrm{P}_{\mathrm{m}}$ is equal to

$$
\mathrm{P}_{\mathrm{m}}=\mathrm{V}_{\mathrm{m}} \mathrm{I}_{\mathrm{m}}
$$

Expressions for calculating maximum power point is

$$
\begin{aligned}
P:= & i\left(-i R_{s}-i R_{s h}+\mathrm{I}_{p h} R_{s h}\right. \\
& \left.-n K \text { LambertW }\left(\frac{\mathrm{I}_{0} R_{s h} \mathrm{e}^{-\frac{R_{s h}\left(i-\mathrm{I}_{p h}-\mathrm{I}_{0}\right)}{n K}}}{n K}\right)+\mathrm{I}_{0} R_{s h}\right)
\end{aligned}
$$

To achieve maximum power points the first partial derivatives of power w.r.t current and voltage should be set equal to zero $[19,30]$ :

Maximum power points (MPP) can also be determined graphically as in Fig. (10) and Fig. (11).

\subsection{Fill Factor}

Fill Factor (FF) which is a measurement of the quadratic nature of $\mathrm{I}-\mathrm{V}$ characteristic is another crucial parameter of DSSC. Typically FF for a DSSC varies from 0.6 to 0.8 and decreases with increasing light intensity. Dependence of FF on series and shunt resistance in conventional solar cell is 


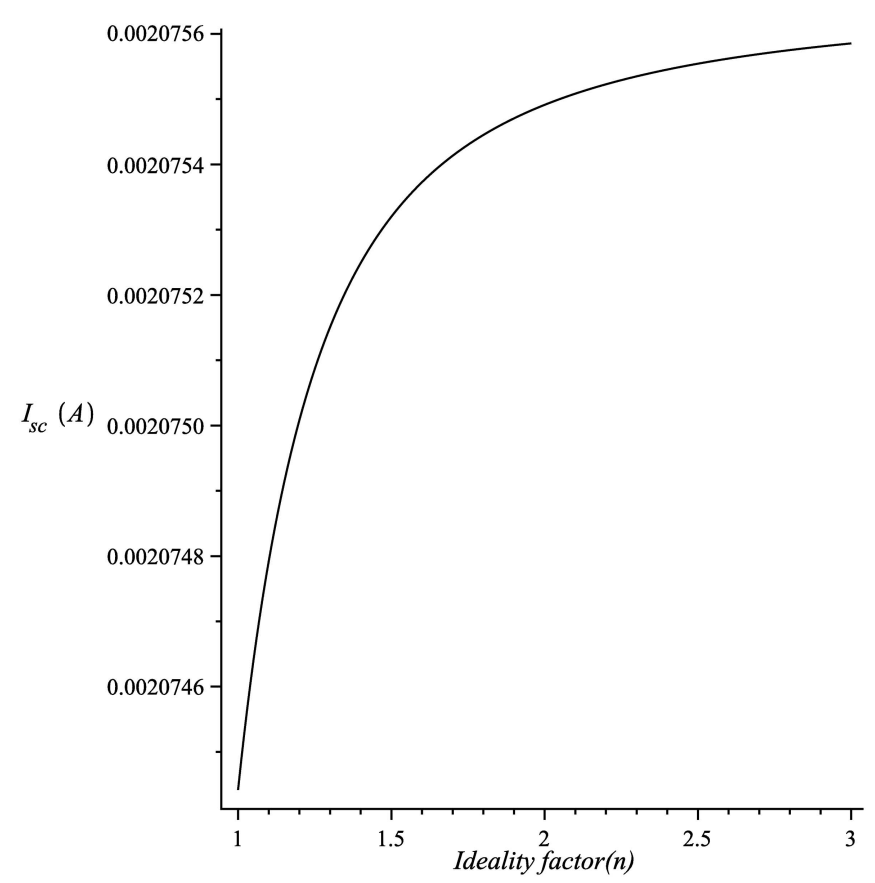

Fig (9). Short circuit current ( $\left.I_{s c}\right)$ vs. ideality factor (n).

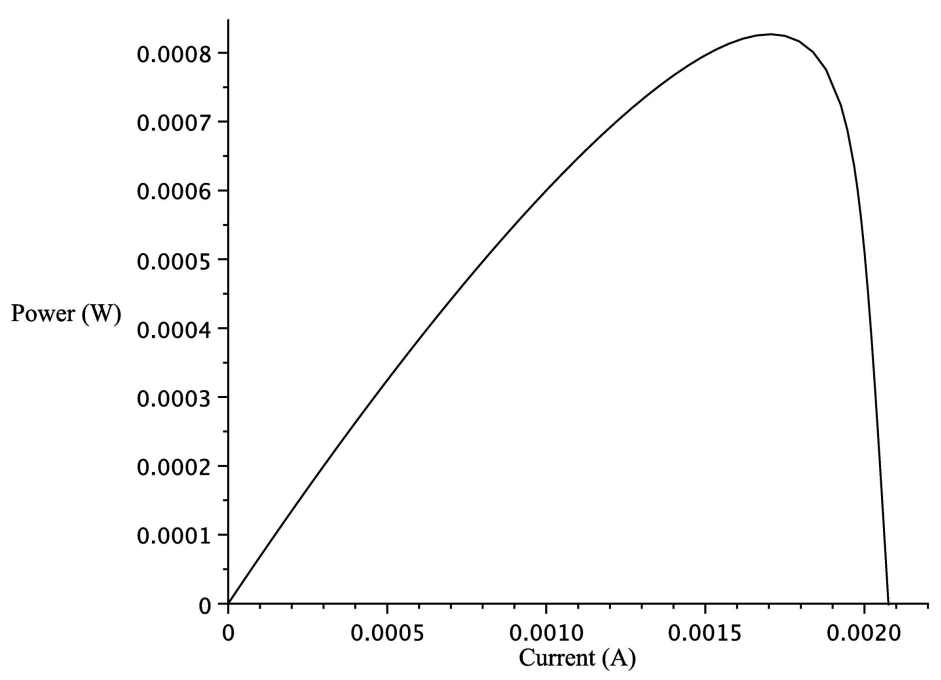

Fig (10). Power (P) vs. current (I).

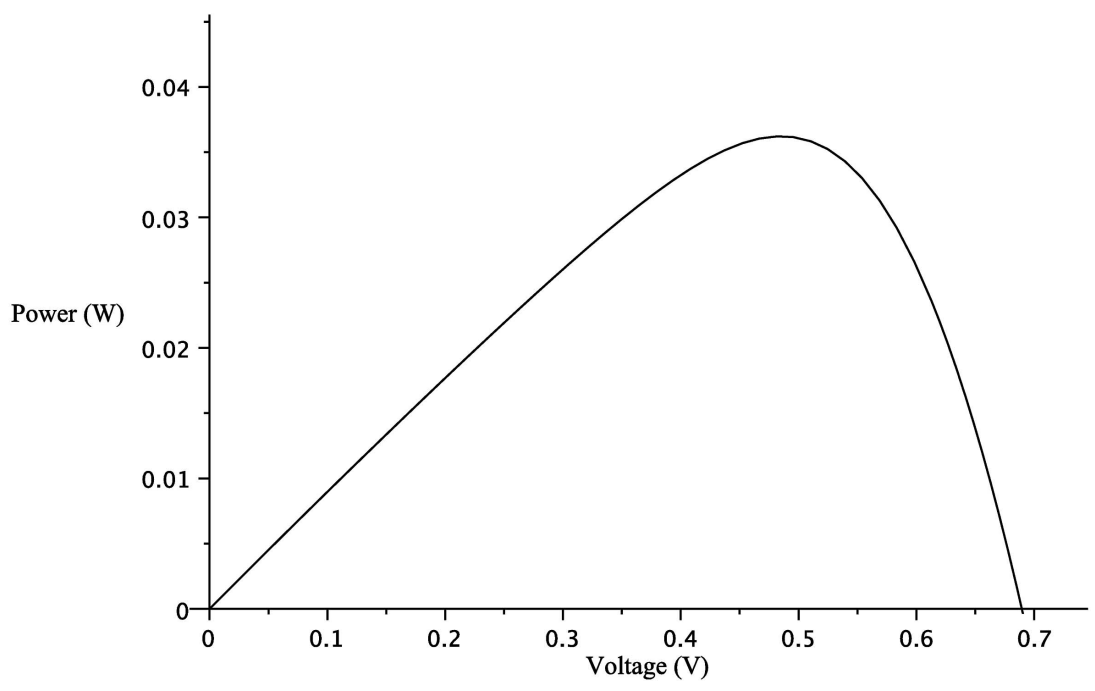

Fig (11). Power (P) vs. voltage (V). 


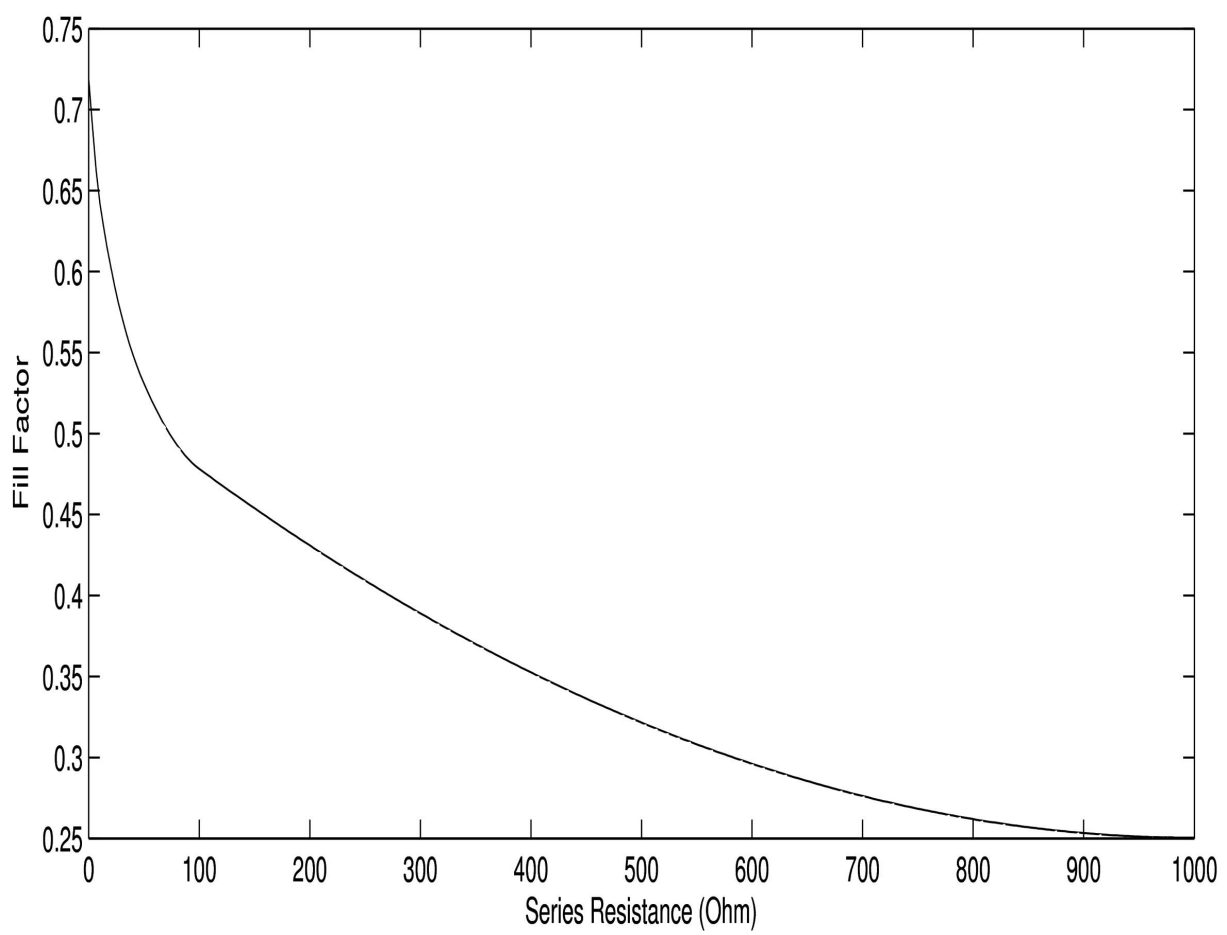

Fig (12). Fill Factor $(F F)$ vs. series resistance $\left(R_{s}\right)$.

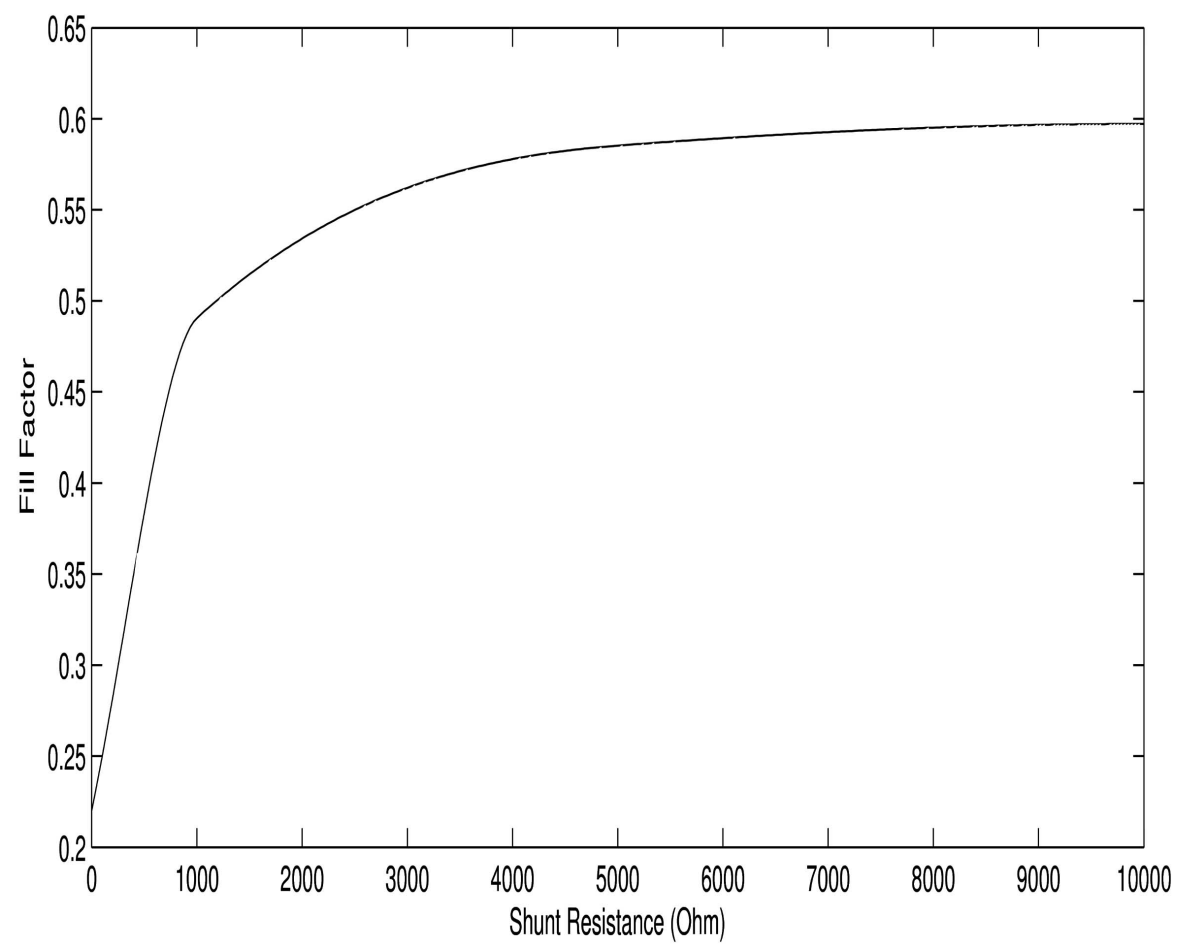

Fig (13). Fill Factor (FF) vs. shunt resistance $\left(\mathrm{R}_{\text {sh }}\right)$.

very well defined $[12,19,31]$. In DSSC low shunt resistance provides a substitute path for light generated current and hence lowers the power output which in turns decreases fill factor. As series resistance in DSSC is lower as compared to conventional solar cells, an improved FF is expected in the case of DSSC.

Variation of FF in correspondence to series and shunt resistance are shown in Fig. (12) and Fig. (13). FF for different
DSSCs are also calculated using various available analytical techniques [32] and summarized in Table $\mathbf{1}$.

$$
\begin{aligned}
& F F_{1}=\frac{\left(V_{m} I_{m}\right)}{\left(V_{0 c} I_{s c}\right)} \\
& F F_{0}=\frac{v_{0 c}-\ln \left(v_{0 c}+0.72\right)}{v_{0 c}+1}
\end{aligned}
$$


Table 1. Parameters Extracted for Nontreated and Carboxylic-Acid-Treated Dye Sensitized Solar Cells (Experimental and WFunction Results)

\begin{tabular}{|c|c|c|c|c|c|c|c|c|c|c|c|c|}
\hline $\begin{array}{l}\text { Cell } \\
\text { Type }\end{array}$ & & $\begin{array}{l}\mathbf{I}_{\mathrm{sc}} \\
(\mathrm{A})\end{array}$ & $\begin{array}{l}\mathbf{V}_{\text {oc }} \\
(\mathbf{V 0}\end{array}$ & $\begin{array}{l}\mathbf{V}_{\mathrm{m}} \\
(\mathbf{V})\end{array}$ & $\begin{array}{l}\mathbf{I}_{\mathbf{m}} \\
(\mathbf{A})\end{array}$ & $\begin{array}{c}\mathbf{P}_{\mathrm{m}} \\
(\mathbf{W}) \times 10^{-4}\end{array}$ & $\mathbf{F F}_{1}$ & $\mathbf{F F}_{2}$ & $\begin{array}{l}\mathbf{R}_{\mathrm{s} 0} \\
(\mathbf{\Omega})\end{array}$ & $\begin{array}{l}\mathbf{R}_{\text {sh0 }} \\
(\Omega)\end{array}$ & $\mathbf{n}$ & $\left(\begin{array}{c}\mathrm{T} \\
\left({ }^{0} \mathrm{C}\right)\end{array}\right.$ \\
\hline \multirow[t]{2}{*}{ Cell 1} & Exp. & 0.0021 & 0.7 & & & & & & & & & \\
\hline & W-fn & 0.00207 & 0.7153 & 0.50986 & 0.00169 & 8.6166 & 0.583 & 0.5789 & 75.3553 & 3227.3 & 2.5 & 20 \\
\hline \multirow[t]{2}{*}{ Cell 2} & Exp. & 0.00206 & 0.704 & & & & & 0.589 & & & 2.5 & \\
\hline & W-fn & 0.00207 & 0.6896 & 0.3698 & 0.0017 & 6.2866 & 0.44 & 0.5774 & 76.509 & 3735.27 & 2.5 & 20 \\
\hline \multirow[t]{2}{*}{ Cell 3} & Exp. & 0.00236 & 0.691 & & & & & 0.584 & & & 2.5 & \\
\hline & W-fn & 0.00207 & 0.6665 & 0.36444 & 0.00169 & 6.15903 & 0.448 & 0.575 & 71.047 & 3318.8 & 2.5 & 20 \\
\hline \multirow[t]{2}{*}{ Cell 4} & Exp. & 0.00202 & 0.701 & & & & & 0.565 & & & 2.5 & \\
\hline & W-fn & 0.00206 & 0.6855 & 0.36806 & 0.00164 & 6.0362 & 0.421 & 0.5439 & 86.616 & 2713.75 & 2.5 & 20 \\
\hline \multirow[t]{2}{*}{ Cell 5} & Exp. & 0.01131 & 0.44 & & & & 0.52 & & & & & \\
\hline & W-fn & 0.01145 & 0.4505 & 0.279 & 0.0086 & 0.2399 & 0.466 & & 14.975 & 784.67 & 2.5 & 25 \\
\hline \multirow[t]{2}{*}{ Cell 6} & Exp. & 0.0013 & 0.55 & & & & & & & & & \\
\hline & W-fn & 0.00128 & 0.5384 & 0.3226 & 0.00143 & 4.6132 & 0.67 & 0.6549 & 62.85 & 12526.31 & 2.1 & 25 \\
\hline
\end{tabular}

Parameters extracted for nontreated and carboxylic-acid-treated dye sensitized solar cells (experimental and w-function results)

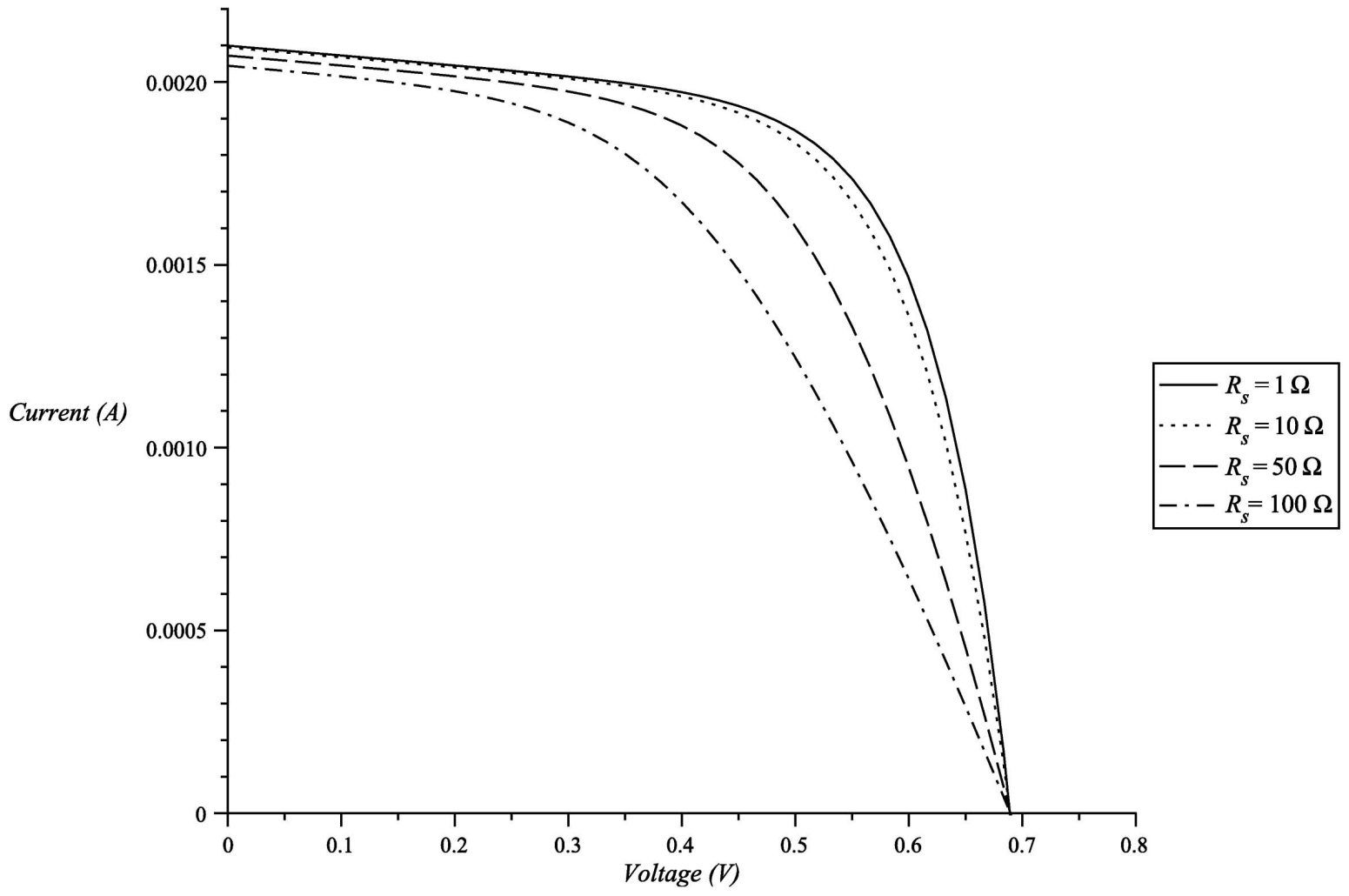

Fig (14). Current (I) vs. Voltage (V) characteristics for a DSSC for different series resistances $\left(\mathrm{R}_{\mathrm{s}}\right)$.

$F F_{2}=F F_{s}\left(1-\frac{\left(v_{0 c}+0.7\right) F F_{s}}{v_{0 c} r_{s h}}\right)$

$F F_{s}=F F_{0}\left(1-1.1 r_{s}\right)+\frac{r_{s}^{2}}{5.4}$

Where

$v_{0 c}=\frac{q}{n k t} V_{0 c} ; r_{s h}=\frac{R_{s h} I_{s c}}{V_{0 c}} ; r_{s}=\frac{R_{s} I_{s c}}{V_{0 c}}$

\section{CONCLUSION}

Though this method has been previously used by Jain et al. and others $[17,30,31,33]$ for conventional solar cell, the same method is equally competent for DSSCs because of similar equivalent circuit. Table 1 summarizes parameters of different DSSCs (treated as well as non treated) determined experimentally and that extracted using $\mathrm{W}$-function technique. In this work authors have applied their technique to six different DSSCs, extracted their parameters, and plotted I-V curves Fig. (14), Fig. (15) and Fig. (16) for different $R_{s}, R_{s h}$ and $T$. 


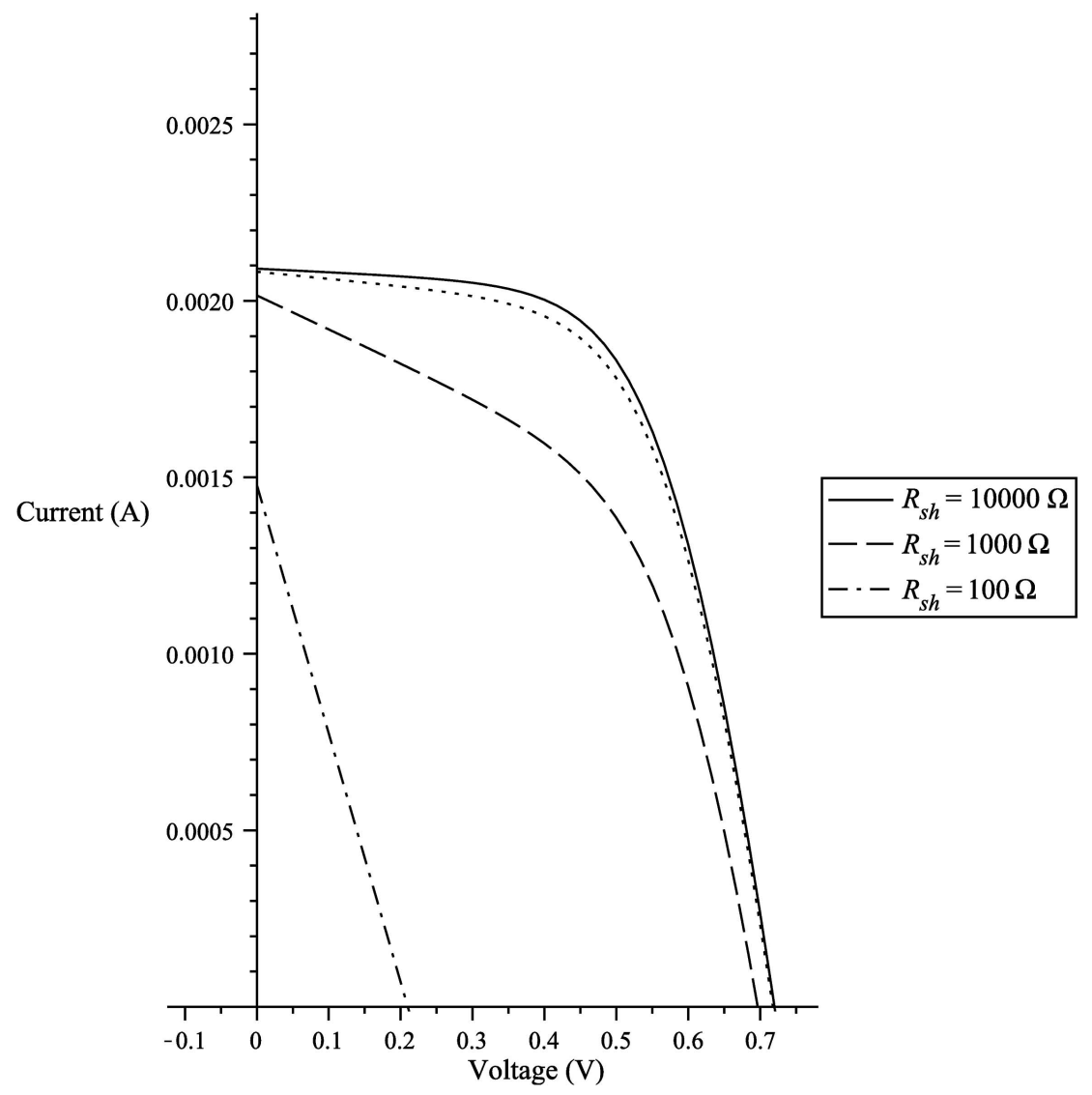

Fig (15). Current (I) vs. Voltage (V) characteristics for a DSSC for different shunt resistances $\left(\mathrm{R}_{\text {sh }}\right)$.

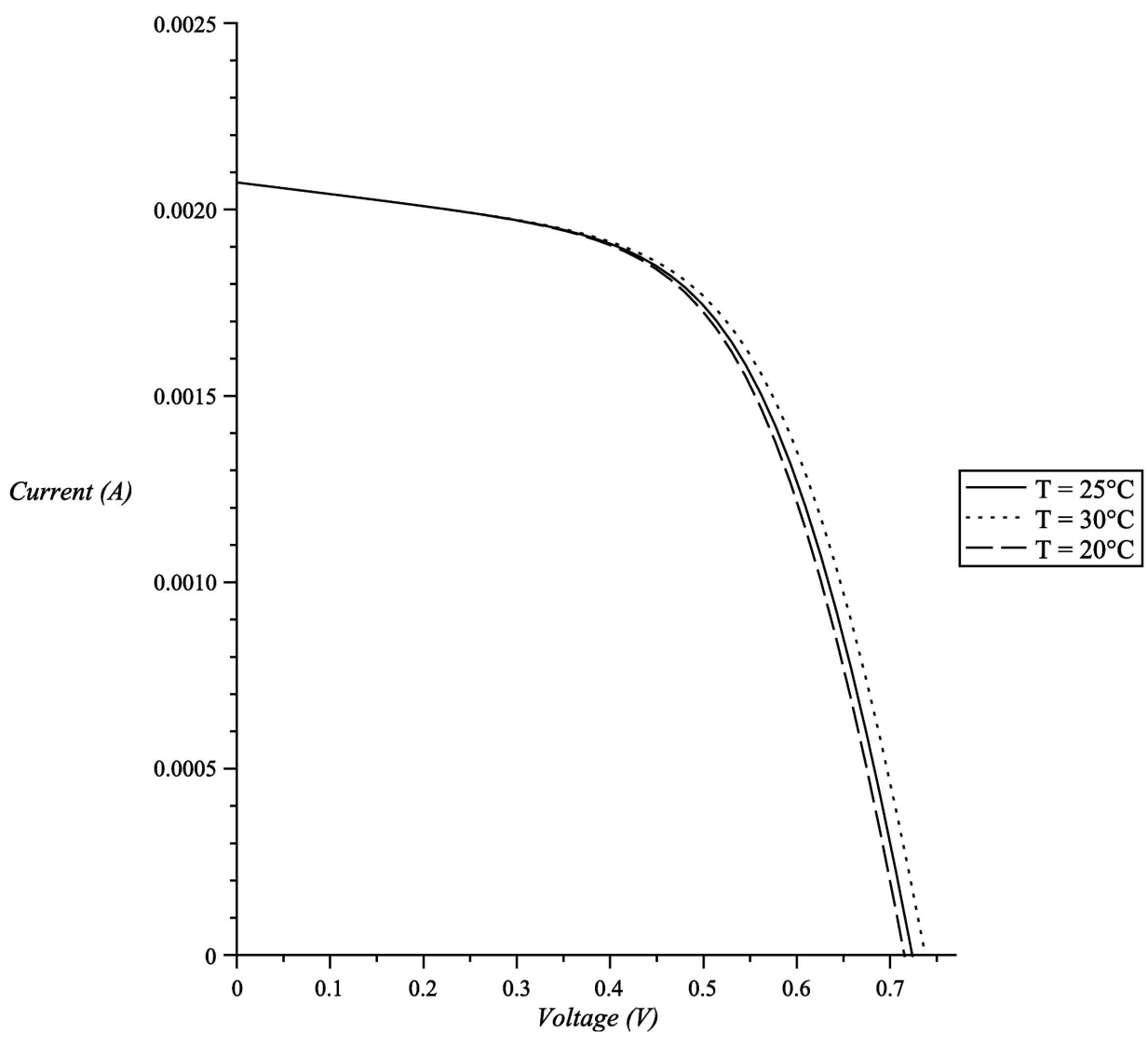

Fig (16). Current (I) vs. Voltage (V) characteristics for a DSSC for different temperatures (T). 
Table 2. Percentage Accuracy for Different DSSCs

\begin{tabular}{|c|c|c|c|}
\hline Cell & \multicolumn{2}{|c|}{ Output Power } & Accuracy \% \\
\hline \hline Cell 1 & Exp. & W fn. & 0.7287 \\
\hline Cell 2 & $1.47 \times 10^{-3}$ & $1.4807 \times 10^{-3}$ & 1.5699 \\
\hline Cell 3 & $1.4502 \times 10^{-3}$ & $1.4275 \times 10^{-3}$ & 15.3954 \\
\hline Cell 4 & $1.6307 \times 10^{-3}$ & $1.3797 \times 10^{-3}$ & 0.3952 \\
\hline Cell 5 & $1.416 \times 10^{-3}$ & $1.4121 \times 10^{-3}$ & 3.6537 \\
\hline Cell 6 & $1.49764 \times 10^{-3}$ & $5.1582 \times 10^{-3}$ & 3.6151 \\
\hline
\end{tabular}

Percentage accuracy for different DSSCs

These are in well accordance with the theoretical results. To validate the method, percentage accuracy is also calculated Table 2.

Variation of different parameters under different conditions is studied graphically and their behavior has been explained. A new analytical method to theoretically study Dye Sensitized solar cell for its model parameters is described using the properties of Lambert W-function. The method involves no approximation. The effects of the series resistance and shunt resistance on the optimum load are studied which are consistent with the results reported in literature. The advantage of the W-Function method is less computation time and exact analytical solution makes it superior over other techniques. Impedance spectroscopy results are also in accordance with theoretical one.

\section{CONFLICT OF INTEREST}

The authors confirm that this article content has no conflicts of interest.

\section{ACKNOWLEDGEMENT}

The authors are thankful to Ms. Neetu Singh and Mr. Anil Kumar for making the DSSC.

\section{REFERENCES}

[1] Regan, B. O.; Gratzel, M. A low-cost, high efficiency solar cell based on dye sensitized solar cell colloidal $\mathrm{TiO} 2$ films. Nature 1991, 353, 737-740.

[2] Gratzel, M.; McEvoy, A. J. Principles and applications of Dye Sensesitized Nanocrystalline solar cells (DSC). Intl PVSEC 14.

[3] Gratzel, M. Dye-sensitized solar cell. J. Photochem. Photobiol. C, Photochem. Rev., 2003, 4, 145-153.

[4] Mc Connell, R.D. Assessment of dye-sensitized solar cell. Renewable Sustainable Energy Rev 2002, 6, 273-295.

[5] Nagata, T.; Murkami, H. Development of Dye-sensitized solar cells. ULVAC Tech. J., 2009, 70 (E), 1-5.

[6] der Maur, M. A.; Gagliardi, A.; Di Carlo, A. Physics based simulation of dye solar cells. Numerical Simulation of Optoelectronic Devices (NUSOD), $10^{\text {th }}$ International Conference, 6-9 Sept, Atlantic, GA., IEEE, 2010, pp.71-72.

[7] Stangl, R.; Ferber, J.; Luther, J. On the modeling of dye sensitized solar cell. Solar Energy Mater Solar Cells, 1998, 54, 255-264.

[8] Ferber, J.; Stangl, R.; Luther, J. An electrical model of the dye sensitized solar cell. Solar Energy Mater. Solar Cells, 1998, 53, 2954.

[9] Bay, L.; West, K. An equivalent circuit approach to the modeling of the dynamics of dye sensitized solar cells. Solar Energy Mater Solar Cells, 2005, 87, 613-628.

[10] Bisquert, J.; Gracia-C, J.; Mora-Sero, I.; Palomares, E. A comparative analysis of photovoltaic principles governing dye- sensitized solar cells and p-n junctions. Proc SPIE, 2004, 521 4959 .

[11] Yong, V.; Ho, S.-T.; Chang, R. P. H. Modeling and simulation of dye-sensitized solar cells. Appl. Phys Lett., 2008, 92,143506.

[12] Koide, N.; Islam, A.; Chiba, Y.; Han, L. Improvement of efficiency of dye-sensitized solar cell based on analysis of equivalent circuit. J. Photochem. Photobiol. A: Chem., 2006, 182, 296-305.

[13] Murayama, M.; Mori, T. Evaluation of treatment effects for high performance dye-sensitized solar cells using equivalent circuit analysis. Thin Solid Films, 2006, 509, 123-126.

[14] Ishibashi, K.-i.; Kimura, Y.; Niwana, M. An extensively valid and stable method for derivation of all parameters of a solar cell from a single current-voltage characteristics. J. Appl. Phys., 2008, 103, 094507.

[15] Murayama, M.; Mori, T. Equivalent circuit analysis of dye sensitized solar cell by using one diode model: effect of Carboxylic acid treatment of $\mathrm{TiO} 2$ electrode. Jpn. J. Appl. Phys., 2006, 45 (1B), 542-545.

[16] Murayama, M.; Mori, T. Novel Tandem cell structure of dye sensitized solar cell for improvement in photocurrent. Thin Solid Films, 2008, 516, 2716-2722.

[17] Jain, A.; Kapoor, A. Exact Analytical solution of the parameters of real solar cells using Lambert W-function. Solar Energy Mater. Solar Cells, 2004, 81, 269-277.

[18] Usami, A.; Shiro, S.; Yo, K.; Hajime, M. Analysis of energy conversion characteristics in dye-sensitized nanocrystalline solar cells (II)-Ideality Factor of the Diode Model for Current-Voltage Characteristics. Jpn. J. Appl. Phys., 2005, QO (4003), 17.

[19] Han, L.; Koide, N.; Chiba, Y.; Mitate, T. Modeling of an equivalent circuit for dye-sensitized solar cells. Appl. Phys. Lett., 2004, 84 (13), 2433-2435.

[20] Han, L.; Koide, N.; Chiba, Y.; Mitate, T.; Islam, A. Modeling of equivalent circuit for dye sensitized solar cells: improvement of efficiency of dye-sensitized solar cell by reducing internal resistance. Comptes. Rendus. Chime., 2006, 9, 645-651.

[21] Kern, R.; Sastrawan, R.; Ferber, J.; Stagnl, R.; Luther, J. Modeling and interpretation of electrical impedance spectra of dye solar cell under open circuit conditions. Electrochimica Acta, 2002, 47, 4213-4225.

[22] Rani, S; Mehra,R.M.ZnO solid-state Dye Sensitized Solar Cells using composite electrolyte of Poly(3Hexylthiophrne-2,5-diyl) and carbon naotubes. Journal of Renewable and sustainable energy2009

[23] Hanmin, T.; Zhang; Xiaobo; Shlkui, Y. An improved method to estimate equivalent circuit parameters in Dye sensitized solar cell. Solar Energy, 2009, 83, 715-720.

[24] Snaith, H. J.; Schmidt-Mende, M.; Gratzel, M. Light intensity, temperature, and thickness dependence of the open-circuit voltage in solid-state dye-sensitized solar cells. Phys, Rev. B, 2006, 74 (045306), 1-6.

[25] Usami, A.; Seki, S.; Mita, Y.; Kobyashi, H.; Miyashiro, H.; Terada, $\mathrm{N}$. Temperature dependence of open circuit voltage in dyesensitized solar cells. Solar Energy Mater. Solar Cells, 2009, 93, 840-842.

[26] Ni, M.; Leung, M. K. H.; Leung, D. Y. C. Theoretical modeling $f$ the electrode thickness effect on maximum power point of dyesensitized solar cell. Can. J. Chem. Eng., 2008, 86, 35-42. 
[27] Shin, B.; Won, J.; T. Son; Kang, Y. S.; Kim, C. K. Barrier effect of dendrons on $\mathrm{TiO} 2$ particles in dye sensitized solar cells. Chem. Commun. 2011, 47, 1734-1736.

[28] Bach, U. Solid-state dye-sensitized mesoprrous TiO2 solar cells; PhD Thesis; ÉCOLE POLYTECHNIQUE FÉDÉRALE DE LAUSANNE: Lausanne, Switzerland.

[29] Berginc, M.; Krasovec, U. O.; Jankovec, M.; Topic, M. The effect of temperature on the performance of dye-sensitized solar cells based on a propyl-methyl-imidazolium iodide electrolyte. Solar Energy Mater. Solar Cells, 2007, 91, 821-828.
[30] Jain, A.; Kapoor, A. A new method to determine diode ideality factor using Lambert-W function. Solar Energy Mater. Solar. Cells, 2005, 85, 391-396.

[31] Jain, A.; Kapoor, A. A new approach to study organic solar cell using Lambert-W function. Solar Energy Mater. Solar Cells, 2005, 86, 391-396.

[32] Green, M. A. Accuracy of analytical expressions for solar cell fill factors. Solar Cells, 1982-1983, 7, 337-340.

[33] Jain, A.; Kapoor, A. Solar cell array parameter using Lambert-W function. Solar Energy Mater. Solar Cells, 2006, 90, 25-31.

Received: February 28, 2012

Revised: April 25, 2012

Accepted: April 30, 2012

(C) Guliani et al.; Licensee Bentham Open.

This is an open access article licensed under the terms of the Creative Commons Attribution Non-Commercial License (http://creativecommons.org/licenses/by-nc/3.0/) which permits unrestricted, non-commercial use, distribution and reproduction in any medium, provided the work is properly cited. 